\title{
Identification of major crop production constraints in debub ari district, south omo zone, southern Ethiopia
}

\begin{abstract}
A survey was carried out during 2016 at Debub Ari, South Omo zone, SNNPRS, Ethiopia to identify the major crop production constraints. Before the inception of the study, the team made short meeting at JARC for the way of interview and given direction on the sampling method and the data to be collected. Then the whole multidisciplinary team was started the work by collecting secondary data from zonal and woreda respective offices. Discussion was made with woreda respective offices to get information with regard to the important preliminary conditions for the study such as selection of the representative kebele for the district, accessibility of the kebele's and the general background of the district. Primary data were collected through discussion between the disciplinary based sub-groups and the corresponding farmers' sub-groups. For the purpose of discussion, the farmers were grouped in to three interviewee subgroups of plant breeders, agronomists and protection researchers each containing females, youths and male elders with proportionate number and participated in the discussion. The discussion was guided by the checklist prepared by multidisciplinary team at regional level and issues raised during discussion were incorporated. Visual observations were also made at farm level. Upon completion of the sub-group level discussion, information particularly agricultural production and production related constraints identified by each sub-groups of farmers were summarized together. Then, all informant farmers were gathered as one group and summarized series of constraints had been briefed to them and then they ranked the problems by consensus in order of their importance. Based on the study, in Debub Ari woreda there is no improved crop variety and package use, not used improved agronomic practice, serious disease andpests, no market institution, information, linkage, accessibility and weak processing of end product and lack of post-harvest handling and food processing technology on fruit, root and tuber crops.
\end{abstract}

Keywords: major crop production constraints, insect pests, farming system
Volume 2 Issue 6 - 2018

\author{
Biruk Gezahegn, Wodajo Gebire, Kedir \\ Bamud \\ Southern Agricultural Research Institute, Jinka Agricultural \\ Research Center, Ethiopia
}

Correspondence: Biruk Gezahegn, Southern Agricultural Research Institute, Jinka Agricultural Research Center, PO Box 96, Jinka, Ethiopia, Email gezahagnb@yahoo.com

Received: April 24, 2018| Published: December 14, 2018

\section{Introduction}

Agriculture is the most important determinant of the Southern Nations, Nationality and Peoples' Region's economy and it will continue to play the leading role in the overall economy development of the region. The livelihood of over $93 \%$ of the people of the region dependent on it, however, agricultural system in the region is at subsistence level and food insecurity problem is increasing at alarming rate. ${ }^{1}$ Moreover, rapid natural resource degradation is prevalent. The food insecurity problem is caused by complex of factors ranging from natural ones such as recurrent drought, degradation of natural resources, pest infestation to institutional one which includes population pressure, lack of appropriate technologies, weak institutional support and lack of alternative employment. ${ }^{2}$ Therefore, there is a greater need to increase agricultural production and productivity, increase in supply of industrial raw materials and production of export products, maintenance and improvement and judicious use of natural resources. Though such a big goal is can be realized through coordinated efforts of various development institutes, the roles and contribution of the agricultural research and development institutes are believed to be irreplaceable and indispensable. Over the last five decades, researchers and extensions have put much effort to generate improved agricultural production technologies and deliver to the users. ${ }^{3}$ Despite that several technologies have been developed, the conventional agricultural research and innovation pursued in the past has not been very successful to deliver appropriate technologies to the end users. As a result, very few technologies developed previously are adopted by the end users and a considerable number of technologies are shelved or kept in laboratory without significant contribution to the objective they are designed for. This is due to several factors, of which the important once is usually the critical process by which information is collected at grass root level from farmers and pastoralists to understand their specific farming system, production practices and production problems and their technology need is ignored. A topbottom approach that dominantly centered researchers/ professional attitudes has been followed since long time for both research planning and technology generation. The technologies generated in this way might not address the real problems of the farming community as they were users' demand-driven and hence the farming community would be passive recipient of the new technology. The research approaches have also been blamed for not targeting agro-ecologies and for disregarding the valuable indigenous technical knowledge's. After the successful completion of AGP-1, AGP-2 has been started by adding additional components. One of the components which added in the second phase was Agricultural Research with the general objective to increase the supply of demand driven agricultural technologies that directly link to the other components and specific objectives of Technology adaptation and generation, Pre-extension demonstration and participatory on-farm technology piloting through FRGs and Source technology production and Capacity development. For 
the successful completion of these objectives there should be need assessments in the respective AGP-2 mandated districts.

The five year program has been started in year 2015. During the first year of the program, two sets of assessments were planned to be conducted to inform detailed annual planning. The first focuses on needs assessment to identify organizational capacity gaps at national and regional levels to determine priority capacity building interventions to be supported through the research component and this is envisaged to ensure that the investments be demand driven. The second set of need assessment activities were focus on identification of agricultural production constraints at district level and this will serve as a basis for planning research activities to be implemented under technology adaptation and generation by the different research centers beginning from the second year of the program.

The assessment study is a take-off for the subsequent research and extension activities and meant to identify agro-ecology based agricultural production constraints and technology needs of the farming, agro-pastoral and pastoral community. Therefore The objective of this assessment was to spell out the constraints of agricultural production and needs of technology using community level participatory planning (CLPP) approach in the selected woreda's of AGP-2 mandated districts.

With specific objectives of:

i. To identify farmers' technology needs.

ii. To understand farmers' indigenous technical knowledge (ITK)

iii. To analyze and prioritize the major agricultural production problems

iv. To better understand and describe the existing conditions of the farming system, and production practices in the agro-ecology and avail information to researchers and development workers.

\section{Material and methods}

\section{The study methodology and procedures}

Before the inception of the study, the team made short meeting at JARC for the way of interview and given direction on the sampling method and the data to be collected. Then the whole multidisciplinary team was started the work by collecting secondary data from zonal and woreda respective offices. Discussion was made with woreda respective offices to get information with regard to the important preliminary conditions for the study such as selection of the representative kebele for the district, accessibility of the kebele's and the general background of the district.

Primary data were collected through discussion between the disciplinary based sub-groups and the corresponding farmers' subgroups. For the purpose of discussion, the farmers were grouped in to three interviewee sub-groups of plant breeders, agronomists and protection researchers each containing females, youths and male elders with proportionate number and participated in the discussion. The discussion was guided by the checklist prepared by multidisciplinary team at regional level and issues raised during discussion were incorporated. Visual observations were also made at farm level.

Upon completion of the sub-group level discussion, information particularly agricultural production and production related constraints identified by each sub-groups of farmers were summarized together.
Then, all informant farmers were gathered as one group and summarized series of constraints had been briefed to them and then they ranked the problems by consensus in order of their importance. Following the field study, disciplinary based data organization, analysis, and report writing were undertaken. Finally, the whole findings were produced in this report.

\section{Sampling method (sample size determination and cluster selection)}

Sample size was estimated as the number of households required to ensure representativeness at the district level and to achieve the objective of assessing technology demand in the districts. Profiles were collected from Woreda offices, AGP-2 focal persons of the woreda, technical committee. Then the woreda was clustered in to respective administration and agro-ecology for the purpose of sampling. Based on this from the woreda $20 \%$ of the PA's were selected for the key informant interview. CLPP was based on target commodities by using cluster approach and the cluster districts.

In the selected PA's

1. Office of the Agriculture with administration and PA manager selection of participants on the discussion were identified and appointed.

2. Key informants from elders, females and youths were then selected based on the PA population (about $20 \%$ of the population).

The study used $20 \%$ degree of variability, a $95 \%$ confidence level, five percent margin of error, based on the formula; ${ }^{4}$

$\mathrm{n}=\mathrm{P}(1-\mathrm{P}) /\left\{\mathrm{A}^{2} / \mathrm{Z}^{2}+\mathrm{P}(1-\mathrm{P}) / \mathrm{N}\right\} / \mathrm{R}$

Where; $\mathrm{n}=$ sample size required

$\mathrm{N}=$ number of people in the population

$\mathrm{P}=$ estimated variance in population $(0.2$ for $80-20)$

$\mathrm{A}=$ Precision desired (i.e., $0.03,0.05,0.1$ for $3 \%, 5 \%, 10 \%$ )

$\mathrm{Z}=$ based on confidence level: 1.96 for $95 \%$ confidence,

$\mathrm{R}=$ estimated Response rate

Therefore based on this from each district the sampled numbers are described below (Table 1).

Table I Study districts and PA's with sample number

\begin{tabular}{llll}
\hline $\begin{array}{l}\text { District/ } \\
\text { woreda }\end{array}$ & Sampled PA & Total HH & Sampled HH \\
\hline Debub Ari & 8 & 5301 & 1060 \\
\hline
\end{tabular}

\section{The study agro-ecology}

This study was conducted in South Omo zone AGP-2 mandated woreda of Debub Ari Woreda. Debub Ari woreda is one of the eight woreda's in South Omo zone with an area of $1,520 \mathrm{~km}^{2}$ and is located at $5^{0} .67^{\prime}-6^{0} .19^{\prime} \mathrm{N} \& 36^{0} .30^{\prime}-36^{0} .73^{\prime} \mathrm{E}$ and has a human population of 219,708 . The total forest coverage of the woreda was divided by natural forest $9476.43 \mathrm{ha}$, artificial forest 1455.05 ha, government enclosure forests 3556.8 ha, cooperative forest 938.08 ha and bamboo forest 1640 ha. The population density of the woreda is 144.4 persons per $\mathrm{km}^{2}$. The woreda is bordering with Semen Ari woreda in north, Mago national park in South, Salamago woreda in west, Malle woreda in east and BenaTsemay woreda in South East.there are 48 kebeles 
in the woreda. The altitude of the woreda ranges between $500 \mathrm{~m}$ a.s.1 and $3000 \mathrm{~m}$ a.s.l. The traditional agro ecologies Dega, woina-dega and kola Covers 30, 65 and 5 percent respectively of the total areas. The woreda has a rain fall pattern of bimodal type/Belg = FebruaryApril and Meher=July-September/. The mean annual rainfall ranges between $601-1600 \mathrm{~mm}$. The mean annual temperature ranges between $10-1^{\circ} \mathrm{c}$ and greater than $27.5^{\circ} \mathrm{C}$. The woreda has an animal resource with an estimate of about 202,018 cattle, 108,167 sheep, 52,160 goats, 14,113 equines, 117,519 chickens and more than 15,000 bee families. Maize, sorghum, barley, wheat, teff and coffee are the major crops grown in the area. Regarding the land use, the proportion of cultivated land, grazing land ,forest land, cultivable land, non- cultivable land and others is $17,15.08,22.43,8.3,15.36$ and 21.81 percent respectively .The Ari ethnic group is the only one in the woreda with mixed/croplivestock/ farming system .

\section{Result and discussion}

Major crop production, farming systems, agronomic practice/cropping pattern and pests in high-land areas of debub ari woreda

\section{Major crop productions in high-land areas of debub ari woreda}

The major crops grown in the high land areas of South Ari woreda are cereals (maize, sorghum, barley, wheat and teff) pulse and oils (common bean, faba bean and linseed)root and tuber (enset, taro, sweet potato, cassava and Irish potato) fruits (avocado, banana, mango, and papaya) coffee and spices (coffee, coriander, ginger, tenadam, nechsar, dinbilal, erdd) and vegetables (cabbages, head cabbage, onion, beet root, garlic, spinach plant, pepper, tomato, carrot)in respective order of their total production and potential.

\section{Farming system and agronomic practice/cropping pattern in high-land areas of debub ari woreda}

The major cropping season in high land areas of South Ari woreda are;'Belg' and 'Mehere' farmers produce their major crops by rain fed and they have traditional irrigation practice for vegetables on dry 'bega' season. The major agronomic practice/cropping pattern/ is double cropping, rely cropping, inter cropping, mono cropping and crop rotation which is practiced deliberately but not in scientific manner.

In order to maintain soil fertility, farmers apply organic fertilizers 'manure' on home garden and have no practice on farm land except inorganic fertilizer which obtained from woreda agricultural office. Pulses (field pea, faba bean and common bean) are used in the cropping pattern as soil fertility improving crops. Seeds of major crops are obtained from local market except maize and vegetables. Recently farmers used common bean improved variety seed.

Land preparation is mainly done by oxen and the frequency of tillage determined by crop type, soil type and oxen availability. Maize; teff; wheat; and linseed are planted at fourth frequency of tillage. Sorghum, barley, common bean; field pea and faba bean are planted at third (first two) and second tillage respectively. Maize; Irish potato; sweet potato and carrot are planted by row with recommended seed rate and the rest of major crops are planted by broadcasting with farmers seed rate.

\section{Major pests in the high-land areas of debub ari woreda (Table 2)}

Table 2 The major pests in the high land areas South Ari woreda in terms of crop type

\begin{tabular}{|c|c|c|c|c|}
\hline No. & Crop type & Major insect pest & Major disease & Weeds \\
\hline I & Maize & stalk borer, aphid, weevil, mole rat, cut worms & $\begin{array}{l}\text { Maize Lethal Necrosis Disease (MLND) and } \\
\text { smut }\end{array}$ & \multirow{21}{*}{$\begin{array}{l}\text { Seksi,Amaranthus(hukuma), } \\
\text { kuskuta spp.(konene), } \\
\text { Bermuda grass(gilma), } \\
\text { Guzotisscabra spp.(mech), } \\
\text { Commelinabenghalensis(aba } \\
\text { ayele) and Cynodondactylon } \\
\text { (serdo) }\end{array}$} \\
\hline 2 & Sorghum & Stalk borer, weevil, mole rat, bird & Smut and anthracnose & \\
\hline 3 & Barley & Brown wheat mites, Weevil, & Rust and Smut & \\
\hline 4 & Wheat & Brown wheat mites & Rust and Smut & \\
\hline 5 & Teff & Brown wheat mites & Smut and rust & \\
\hline 6 & Common bean & Leaf cutters, pod worms & Common Wilting diseases & \\
\hline 7 & Field pea & Aphid, pod worms & Common Wilting diseases & \\
\hline 8 & Faba bean & Aphid, pod worms & Common Wilting diseases & \\
\hline 9 & Enset & Root mealy bug, mole rat & Enset bacterial wilt & \\
\hline 10 & Sweet potato & Sweet potato weevil, mole rat, cut worms & & \\
\hline II & Irish potato & Spotted leaf beetles, weevil, mole rat, cut worms & Early and Late blight, bacterial wilt & \\
\hline 12 & Beet root & Mole rat, cut worms & Blight & \\
\hline 13 & Onion & Crickets, cut worms & Rusts, Botrytis leaf blight & \\
\hline 14 & Garlic & & Botrytis leaf blight & \\
\hline 15 & Cabbages & Aphid, cabbage looper & & \\
\hline 16 & Hot pepper & Aphids, cut worms & Common Wilting diseases & \\
\hline 17 & Tomato & Tomato fruit worms & Blights & \\
\hline 18 & Banana & Mole rat & Banana bacterial wilt/pucarium wilt & \\
\hline 19 & Avocado & Fruit fly & Anthracnose and phaytophthora & \\
\hline 20 & Mango & Fruit fly & $\begin{array}{l}\text { Anthracnose, mangoscap, algaleaf spot and } \\
\text { dendritic spot }\end{array}$ & \\
\hline 21 & Coffee & & $\begin{array}{l}\text { Coffee berry disease, bacterial wilt, coffee } \\
\text { leaf rust }\end{array}$ & \\
\hline
\end{tabular}


From the above mention EnsetBcterial Wilt (EBW) on banana and enset, Maize Lethal Necrosis Disease (MLND) on maize, blight on potato and tomato, anthracnose on mango, botrytis leaf blight on onion and garlic and rust on barley and wheat are the most serious diseases in the study area. Insect pest like mole rat specially on root and tuber crops, cut worms on vegetables, pulses and cereal crops, crickets on onion, brown wheat mite on wheat and barley, weevil on storage product, aphid on pulse and vegetable crops (specially on field pea), aphids on field pea and fruit fly on mango and avocado are the most serious. The most serious weeds in the study area are seksi, amaranthus, cuscuta species, bermuda grass, guzotiasscabra species, commelinabenghalensis and cynodondactylon.

Major crops production, farming systems, agronomic practice/cropping pattern and pests in mid-land areas of debub ari woreda

\section{Major crop production in mid-land areas of debub ari woreda}

The major crops grown in the mid land areas of South Ari woreda are cereals (maize and sorghum) pulse and oils (common bean and ground nut) root and tuber (Enset, taro, sweet potato, cassava and yam) fruits (avocado, banana, mango, and papaya) coffee and spices (coffee, kororima, ginger and turmeric) and vegetables (cabbages, onion, beet root, garlic, hot pepper, tomato, carrot) in respective order of their total production and potential.

\section{Farming system and agronomic practice/cropping pattern in mid-land areas of debub ari woreda}

The major cropping season in mid land areas of South Ari woreda are; 'Belg' and 'Mehere' farmers produce their major crops by rain fed and they have traditional irrigation practice for vegetables on dry 'bega' season. The major agronomic practice/cropping pattern/ is double cropping (ground nut with maize, common bean with maize), rely cropping (sorghum with maize, sweet potato with maize), mixed cropping (sorghum with maize, common bean with maize), inter cropping (maize with common bean), mono cropping and crop rotation which is practiced deliberately but not in scientific manner. In order to maintain soil fertility, farmers apply organic fertilizers 'manure' on home garden and have no practice on farm land except inorganic fertilizer which obtained from woreda agricultural office. Seeds of major crops are obtained from local market except maize and vegetables. Recently farmers used common bean improved variety seed.

Land preparation is mainly done by oxen and the frequency of tillage determined by crop type, soil type and oxen availability. Maize, onion, ground nut and sweet potato are planted at fourth frequency of tillage. Sorghum and common bean are planted at third (first two) and second tillage respectively. Maize, common bean, ground nut, sweet potato, onion and hot pepper are planted by row with recommended seed rate and the rest of major crops are planted by broadcasting with farmer's seed rate.

\section{Major pests in the mid-land areas of debub ari woreda (Table 3)}

From the above mention Enset Bacterial Wilt (EBW) on banana and Enset, Maize Lethal Necrosis Disease (MLND) on maize, anthracnose on mango and leaf blight on onion are the most serious diseases in the study area. Insect pest like mole rat especially on root and tuber crops, rice black beetle on maize, crickets on onion, weevil on storage product and fruit fly on mango and avocado are the most serious insect pest. Arebermuda grass (gilma), amaranthus (hukuma), commelinabenghalensis (aba ayele) and cynodondactylon (serdo) are most serious weeds in the study area.

Table 3 The major pests in the mid land areas Debub Ari woreda in terms of crop type

\begin{tabular}{|c|c|c|c|c|}
\hline No. & Crop type & Major insect pest & Major disease & Weeds \\
\hline 1 & Maize & $\begin{array}{l}\text { stalk borer, rice black beetle, weevil, mole rat, } \\
\text { rodents }\end{array}$ & Maize lethal necrosis disease, maize ear rot & \multirow{14}{*}{$\begin{array}{l}\text { Bermuda grass(gilma), } \\
\text { Amaranthus(hukuma), } \\
\text { Commelinabenghalensis(aba } \\
\text { ayele), and } \\
\text { Cynodondactylon(serdo) }\end{array}$} \\
\hline 2 & Sorghum & Bird, rodents, weevil & Head smut, anthracnose & \\
\hline 3 & Common bean & Leaf cutters, aphids & Common bacterial wilt & \\
\hline 4 & Ground nut & Mole rat, ground nut bruchid, white grub & & \\
\hline 5 & Enset & mole rat & Enset bacterial wilt & \\
\hline 6 & Sweet potato & mole rat, porcupine (jart), cut worms & & \\
\hline 7 & Onion & Mole rat, crickets & Rusts, leaf blight & \\
\hline 8 & Cabbages & Aphid, cabbages looper & & \\
\hline 9 & Hot pepper & & Bacterial wilt & \\
\hline 10 & Tomato & Bird, tomato fruit worm & Blights & \\
\hline 11 & Banana & & Banana bacterial wilt /pucarium wilt & \\
\hline 11 & Avocado & Fruit fly & & \\
\hline 12 & Mango & Fruit fly & Anthracnose & \\
\hline 13 & Coffee & Coffee stem weevil & Coffee berry disease & \\
\hline
\end{tabular}


Major crop production, farming systems, agronomic practice/cropping pattern and pests in low-land areas of debub ari woreda

\section{Major crop production in low-land areas of debub ari woreda}

The major crops grown in the low land areas of South Ari woreda are cereals (maize, sorghum, teff and pearl millet) pulse and oils (common bean, ground nut, cow pea, sesame, linseed and sunflower) root and tuber (Enset, taro, sweet potato, cassava, yam, Irish potato and taniya) fruits (avocado, banana, mango, papaya, citrus and pineapple) coffee and spices (coffee, ginger and turmeric) and vegetables (cabbages, onion, beet root, garlic, hot pepper, tomato, carrot, pumpkin and moringa) in respective order of their total production and potential.

\section{Farming system and agronomic practice/cropping pattern in low land areas debub ari woreda}

The major cropping season in low-land areas of South Ari woreda are ;'Belg' and 'Mehere' farmers produce their major crops by rain fed and they have traditional irrigation practice for vegetables on dry 'bega' season. The major agronomic practice/cropping pattern/ is double cropping (common bean with maize), rely cropping (sweet potato with maize), mixed cropping (sorghum with maize, common bean with maize), inter cropping (maize with common bean) and mono cropping which is practiced deliberately but not in scientific manner.
In order to maintain soil fertility, farmers apply organic fertilizers 'manure' on home garden and have no practice on farm land except inorganic fertilizer which obtained from woreda agricultural office. Also they used crop rotation to improved soil fertility purposely.

Pulses (ground nut and common bean) are used in the cropping pattern as soil fertility improving crops. Seeds of major crops are obtained from local market except maize, sesame and vegetables. Recently farmers used common bean improved variety seed. Land preparation is mainly done by oxen and hand hoeing; the frequency of tillage determined by crop type, soil type and oxen availability. Maize, teff, sorghum, sweet potato, onion, and common bean are planted at two up to four frequency of tillage. Maize, common bean, ground nut and sweet potato are planted by row with recommended seed rate and the rest of major crops are planted by broadcasting with farmer's seed rate.

\section{Major pests in the low- land areas of debub ari woreda (Table 4)}

From the above mention Enset Bacterial Wilt (EBW) on banana and enset, Maize Lethal Necrosis Disease (MLND) on maize and leaf blight on onion are the most serious diseases in the study area. Insect pest like rice black beetle on maize, termite on maize, stalk borer on maize, sorghum and finger millet, weevil on storage product and fruit fly on mango are the most serious. The most serious weeds are Bermuda grass (gilma) and Cyprus spp.

Table 4 The major pests in the low- land areas Debub Ari woreda in terms of crop type

\begin{tabular}{|c|c|c|c|c|}
\hline No. & Crop type & Major Insect pest & Major Disease & Weeds \\
\hline 1 & Maize & $\begin{array}{l}\text { stalk borer, rice black beetle, termite, } \\
\text { weevil, mole rat, rodents }\end{array}$ & $\begin{array}{l}\text { Maize lethal necrosis } \\
\text { disease(MLND), maize ear rot }\end{array}$ & \\
\hline 3 & Common bean & Aphid, pod worms, porcupine (jart) & Common bacterial wilt & \\
\hline 4 & Ground nut & $\begin{array}{l}\text { porcupine (jart), Mole rat, ground nut } \\
\text { bruchid, white grub }\end{array}$ & & \\
\hline 5 & Enset & mole rat & Enset bacterial wilt & \\
\hline 6 & Sweet potato & $\begin{array}{l}\text { Sweet potato weevil, mole rat, porcupine, } \\
\text { cut worms, white worms }\end{array}$ & & \\
\hline 7 & Onion & Mole rat, crickets & leaf blight & \\
\hline 8 & Cabbages & Aphid, cabbage looper & & Bermuda grass (gilma) Cyprus spp. \\
\hline 9 & Hot pepper & Cut worms & Bacterial wilt & And Cynodondactylon (serdo) \\
\hline 10 & Tomato & Bird, tomato fruit worm & Blight & \\
\hline 11 & Banana & & Banana bacterial wilt & \\
\hline 11 & Avocado & Fruit fly & & \\
\hline 12 & Mango & Fruit fly & & \\
\hline 13 & Coffee & Coffee steam weevil & Coffee berry disease & \\
\hline 14 & Moringa & Aphid & & \\
\hline 15 & Sesame & Aphid & Bacterial wilt & \\
\hline 16 & Teff & & Rust & \\
\hline
\end{tabular}

\section{Harvesting Techniques}

Major crops harvested manually by household members and social groups (debo, edir, 1 to 5 groups, etc). The harvested crops transported with horse, mule and human power and then stored at different storage

system. Life span of stored crop is depends on crop type, availability pesticide and amount of producer. Maize is stored in gotera; sorghum, wheat and barley in hip; haricot bean, field pea and faba bean after harvested they stalk on tree and ladder and then trashed after dry enough and stored in quintal. 


\section{Marketing constraints}

In South Ari woreda, there is no market linkage, no market information and no accessibility in terms of road and alternative market. Also they produce not standardize quality due to lack of awareness, lack of market competition and accessibility. In case of coffee growing areas South Ari woreda farmers have no market alternative except one private coffee processor and supplier. The market linkage is too weak and no market institution that attract the producer. So, a farmer does not return as their potential producer from the cash crop. The only credit access in most high land areas is Omo Micro Finance. In the study areas there are number of governmental institution that serves the society. The major institution is kebele agricultural office, school, health post and micro finance. Farmers trained by extension agents on agricultural health and supported by different experts at different level of constraints they face.

\section{Summery}

In general, in South Ari woreda the major crop production constraints in terms of improved crop variety and package use, agronomic practice, disease and pests, processing and marketing:-

i. Except maize, common bean and vegetables crop all other crops are grown by using local varieties.

ii. Not use improved agronomic practices (row planting, fallowing, crop rotation etc.) and also they not use inorganic fertilizer.

iii. Serious disease, insect and weeds on major crops iv. No market institution, information, linkage, accessibility and weak processing of end product

v. Lack of post-harvest handling and food processing technology on fruit, root and tuber crops.

\section{Acknowledgments}

None.

\section{Conflicts of interest}

Authors declare that their is no conflict of interest.

\section{References}

1. Federal republic of ethiopia: selected issues series. International ministry fund country report No.08/259. 2009;5:26.

2. Matous P, Y Tado. Role of extension and ethno-religious network in acceptance of resource conserving agricultural resources among Ethiopian farmer. International journal of agricultural sustainability. 2013;11(4):301-316.

3. Almekinders SJM, Elings A. Collaboration, crop improvement in perspective. Euphytica. 2001.122:425-438.

4. Wilson PD, Hadley S. Ramsden, et al. Measuring and explaining technical efficiency in UK potato production. Journal of Agricultural Economics. 1988;49(3):294-305. 